\title{
Mono-/dihydroxybenzoic acid esters and phenol pyridinium derivatives as inhibitors of the mammalian carbonic anhydrase isoforms I, II, VII, IX, XII and XIV
}

\author{
Fabrizio Carta*, Daniela Vullo, Alfonso Maresca, Andrea Scozzafava, Claudiu T. Supuran* \\ Università degli Studi di Firenze, Polo Scientifico, Laboratorio di Chimica Bioinorganica, Rm. 188, Via della Lastruccia 3, 50019 Sesto Fiorentino (Florence), Italy
}

\section{A R T I C L E I N F O}

Article history:

Available online 17 May 2012

\section{Keywords:}

Carbonic anhydrase

Phenol

Hydroxy-/dihydroxybenzoic acid

Dopamine

Aminophenol

\begin{abstract}
A B S T R A C T
Using hydroxy-/dihydroxybenzoic acids as leads, a series of methyl, ethyl and iso-propyl esters of 4-hydroxy-benzoic acid, 2,4-, 2,5-, 2,6-, 3,4-, and 3,5-dihydroxybenzoic acids and of coumaric acid, were obtained and investigated for the inhibition of six mammalian carbonic anhydrase (CA, EC 4.2.1.1) isoforms, that is, the cytosolic CA I, II and VII, and the transmembrane CA IX, XII and XIV, many of which are established drug targets. Other compounds incorporating phenol/catechol moieties were obtained from dopamine by reaction with fluorescein isothiocyanate or with 2,4,6-trisubstituted pyrylium salts. Some aminophenols were also derivatized in a similar manner, by using pyrylium salts. Many of these compounds showed increased inhibitory action compared to the lead compounds from which they were obtained, with efficacy in the submicromolar range against most investigated CA isoforms. As phenols are a class of less investigated CA inhibitors (CAIs) compared to the sulfonamides, and their mechanism of inhibition is less well understood, compounds of the type designed here may be helpful in gaining more insights into these phenomena.
\end{abstract}

(c) 2012 Elsevier Ltd. All rights reserved.

\section{Introduction}

Non-sulfonamide carbonic anhydrase (CA, EC 4.2.1.1) inhibitors (CAIs) were investigated in great detail in the last period. Many new such chemotypes were identified, among which phenols ${ }^{1-4}$ and thiols, ${ }^{5}$ coumarins, thiocoumarins, 2-thioxo-coumarins and 5/6-ring membered (thio)lactones, ${ }^{6-8}$ the antiepileptic drug lacosamide, ${ }^{9}$ polyamines, ${ }^{10}$ some fullerene derivatives ${ }^{11}$ and even compounds expected to bind as CA activators (pyridinium histamine derivatives), ${ }^{12}$ which were observed deeply bound within the enzyme active site (by means of high resolution X-ray crystallography) where usually inhibitors are located. ${ }^{13-15}$

CAIs investigated in detail so far, by means of high resolution $\mathrm{X}$ ray crystallography, belong to three main classes: (i) Zinc binders, such as sulfonamides (and their bioisosteres, including sulfamates, sulfamides, $N$-hydroxysulfonamides, and similar derivatives), ${ }^{13-15}$<smiles>COc1ccccc1OC</smiles>

A<smiles>COc1ccc(OC)cc1</smiles>

B<smiles>COc1ccc(OC)c(OC)c1</smiles>

C

metal complexing anions, ${ }^{16}$ thiols and dithiocarbamates. ${ }^{17}$ They coordinate to the $\mathrm{Zn}(\mathrm{II})$ ion from the enzyme active site, in tetrahedral or trigonal bipyramidal geometries of the $\mathrm{Zn}$ (II) ion; ${ }^{13-17}$ (ii) Compounds anchoring to the non-protein zinc ligand, such as phenols and polyamines. They bind to the zinc-coordinated water molecule/hydroxide ion from the active site, through a network of two hydrogen bonds; ${ }^{8}$ and (iii) Coumarins/thiocoumarins and similar compounds (lactones, coumarin oximes, 2-thioxocoumarins, etc.) acting as 'prodrug inhibitors'. They bind after in situ hydrolysis to 2-hydroxycinnamic acids (or the corresponding compounds formed from thiocoumarins, coumarin oximes or lactones/thiolactones, respectively) in the same active site region as the CA activators, ${ }^{18}$ occluding the entrance to the active site cavity. ${ }^{10}$ Fullerenes $^{13}$ and lacosamide ${ }^{10}$ bind in a similar manner to the hydrolyzed coumarins, ${ }^{10}$ that is, by occluding the entrance to the enzyme active site cavity.<smiles>COc1ccc(C(=O)O)cc1OC</smiles>

D<smiles>COc1cccc(C(=O)O)c1C(=O)O</smiles>

$\mathbf{E}$

\footnotetext{
* Corresponding authors. Tel.: +39 055457 3005; fax: +39 0554573385.

E-mail addresses: fabrizio.carta@unifi.it (F. Carta), claudiu.supuran@unifi.it (C.T. Supuran).
} 
Recently, by means of kinetic measurements and docking experiments, we identified a fourth possible CA inhibition mechanism. ${ }^{1}$ We observed that some hydroxy-/methoxy-substituted benzenes and benzoic acids, of types A-E, acting as low micromolar inhibitors of several CA isozymes, ${ }^{1}$ bind differently of all other CAIs known to date. These compounds were observed to be located between the phenol-binding site and the coumarin-binding site within the enzyme cavity, by using molecular docking. They are thus situated more or less in the middle of the cavity, ${ }^{1}$ exploiting different interactions with amino acid residues and water molecules from the active site compared to other classes of inhibitors investigated so far and mentioned above. In this way, they offer an interesting possibility to design CAIs with a different inhibition profile compared to the clinically used sulfonamides/sulfamates, or the other classes of inhibitors investigated in some detail ultimately, such as the coumarins, dithiocarbamates, etc. However, only very few such derivatives have been investigated so far, and only for their interaction with four CA isoforms (CA I, II, IX and $\mathrm{XII}$ ) in addition to A-E mentioned above. Thus, by using those compounds as leads, we report here a series of esters of hydroxy-/dihydroxy benzoic acids ( 5 regiomers of dihydroxybenzoic acids were investigated, i.e., 2,4-, 2,5-, 2,6-, 3,4-, and 3,5-dihydroxybenzoic acids), as well as other compounds incorporating phenol or catechol moieties and pyridinium/fluorescein functionalities in their molecules, which were investigated for the inhibition of 6 physiologically relevant hCA ( $\mathrm{h}=$ human enzyme) isoforms, i.e., hCA I, II, VII (cytosolic isoforms) and hCA IX, XII and XIV (transmembrane isoforms), many of which are established drug targets.

\section{Chemistry}

The lead molecules for the present drug design study were the hydroxy-/methoxy-substituted benzenes and benzoic acids, of types A-E investigated in the earlier work. ${ }^{1}$ The phenol moiety from a non-sulfonamide CAI is important for the possible anchoring to the zinc coordinated water molecule/hydroxide ion, ${ }^{1,2}$ whereas the $\mathrm{COOH}$ moiety (as carboxylate) when present in a compound, may coordinate to this metal ion. ${ }^{16}$ We thus decided to use hydroxy-/dihydroxy benzoic acids as well as p-coumaric acid as starting materials for obtaining a first group of compounds. The working hypothesis was the following: the $\mathrm{OH}$ moiety/moieties of these compounds will be left free, whereas the $\mathrm{COOH}$ one will be derivatized (as esters) in order to evaluate the structureactivity relationship (SAR) in a series of compounds which are not able any longer to coordinate the $\mathrm{Zn}$ (II) ion as carboxylates (Table 1). Thus, carboxylic acids 1a-7a have been converted to the corresponding methyl-, ethyl and isopropyl esters $\mathbf{1 b - 7 d}$, by a routine esterification procedure involving the reaction between the carboxylic acid and the corresponding alcohol (see Section 5 for details). Some of these compounds were reported earlier in the literature. ${ }^{19-28}$

Another group of derivatives were prepared in such a way as to include pyridinium moieties attached to scaffolds possessing one or two phenolic $\mathrm{OH}$ moieties (Schemes 1 and 2). ${ }^{29,30}$ The presence of the substituted pyridinium moieties was desired because of at least two reasons: sulfonamides incorporating this substitution pattern showed excellent CA inhibitory activity against several isoforms, ${ }^{31}$ and in the X-ray crystal structure of adducts with CA II, a stacking interaction between the 2,4,6-trisubstituted pyridinium ring and the phenyl moiety of Phe 131 from the enzyme cavity has been evidenced. $^{32}$ Such a stacking interaction would be of interest to investigate for non-sulfonamide CAIs, such as the phenols. For introducing chemical diversity, both 2,4,6-trimethylpyrylium perchlorate and 4-phenyl-2,6-dimethyl-pyrylium perchlorate were used to derivatize dopamine $\mathbf{8}$, leading to the pyridinium salts $\mathbf{1 0}$
Table 1

Inhibition data with compounds 1-7, against CA isozymes I, II, VII, IX, XII, and XIV by a stopped-flow technique monitoring the $\mathrm{CO}_{2}$ hydration reaction ${ }^{38}$

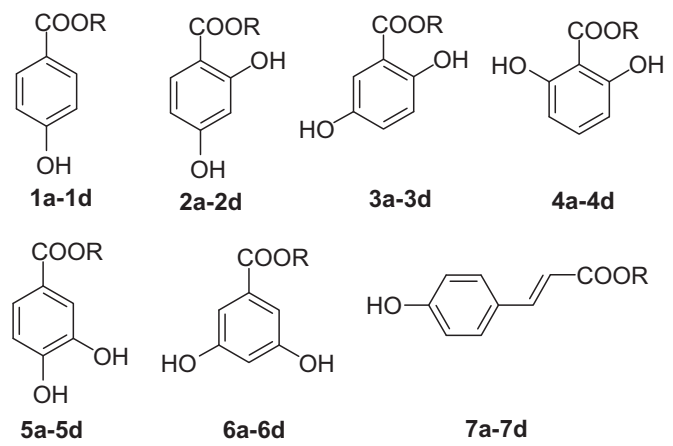

\begin{tabular}{|c|c|c|c|c|c|c|c|}
\hline \multirow[t]{2}{*}{ No. } & \multirow[t]{2}{*}{$\mathrm{R}$} & \multicolumn{6}{|c|}{$K_{\mathrm{I}}^{\mathrm{b}}(\mu \mathrm{M})$} \\
\hline & & hCA I & hCA II & hCA VII & hCA IX & hCA XII & hCA XIV \\
\hline $1 a^{a}$ & $\mathrm{H}$ & 9.8 & 10.6 & 716 & 118 & 4.8 & 34.3 \\
\hline 1b & Me & 2.6 & 3.4 & 0.78 & 5.5 & 0.82 & 4.1 \\
\hline 1c & Et & 7.9 & 4.8 & 8.7 & 8.2 & 8.6 & 7.7 \\
\hline 1d & $i-\operatorname{Pr}$ & 7.3 & 4.4 & 0.94 & 7.4 & 8.5 & 0.82 \\
\hline $2 a$ & $\mathrm{H}$ & 5.2 & 4.9 & 72 & 68 & 7.5 & 70 \\
\hline $2 b$ & Me & 0.83 & 0.76 & 0.85 & 0.89 & 0.95 & 0.86 \\
\hline $2 c$ & Et & 0.63 & 0.52 & 0.81 & 0.82 & 0.77 & 0.74 \\
\hline 2d & $i-\operatorname{Pr}$ & 0.39 & 0.51 & 0.54 & 0.31 & 0.50 & 0.33 \\
\hline $3 a$ & $\mathrm{H}$ & 4.2 & 4.1 & 68 & 6.6 & 7.3 & 67 \\
\hline 3b & Me & 0.82 & 0.77 & 8.3 & 0.84 & 0.83 & 0.80 \\
\hline $3 c$ & Et & 0.71 & 0.69 & 0.83 & 0.86 & 0.75 & 0.77 \\
\hline 3d & $i-\operatorname{Pr}$ & 0.97 & 0.58 & 0.84 & 0.81 & 0.82 & 0.84 \\
\hline $4 a$ & $\mathrm{H}$ & 5.7 & 5.2 & 6.6 & 5.9 & 7.2 & 6.5 \\
\hline $4 b$ & $\mathrm{Me}$ & 0.68 & 0.70 & 0.71 & 0.81 & 0.72 & 0.76 \\
\hline $4 c$ & Et & 0.67 & 0.56 & 0.76 & 0.78 & 0.84 & 0.82 \\
\hline 4d & $i$-Pr & 0.72 & 0.53 & 0.80 & 0.79 & 0.88 & 0.83 \\
\hline $\mathbf{5 a}^{\mathrm{b}}$ & $\mathrm{H}$ & 1.08 & 0.47 & 7.87 & 4.45 & 4.09 & 0.69 \\
\hline $5 b$ & Me & 0.71 & 0.58 & 0.81 & 0.79 & 0.96 & 0.89 \\
\hline $5 c$ & Et & 0.65 & 0.61 & 0.75 & 0.78 & 0.83 & 0.86 \\
\hline $5 d$ & $i-\operatorname{Pr}$ & 0.83 & 0.42 & 0.91 & 0.80 & 0.86 & 0.77 \\
\hline $6 a^{b}$ & $\mathrm{H}$ & 0.55 & 0.51 & 7.17 & 4.41 & 3.67 & 0.65 \\
\hline $6 \mathbf{b}$ & Me & 0.77 & 0.69 & 0.78 & 0.81 & 0.84 & 0.78 \\
\hline $6 c$ & Et & 0.69 & 0.66 & 0.90 & 0.91 & 0.85 & 0.83 \\
\hline 6d & $i-\operatorname{Pr}$ & 0.92 & 0.70 & 0.89 & 0.90 & 0.89 & 0.85 \\
\hline $7^{\mathrm{ac}}$ & $\mathrm{H}$ & 1.07 & 0.98 & 5.23 & 5.33 & 8.01 & 6.68 \\
\hline $7 \mathbf{b}$ & Me & 0.78 & 0.80 & 0.82 & 0.85 & 0.81 & 0.83 \\
\hline 7c & Et & 0.32 & 0.71 & 0.85 & 0.61 & 0.49 & 0.80 \\
\hline 7d & $i-\operatorname{Pr}$ & 0.54 & 0.52 & 0.69 & 0.68 & 0.76 & 0.73 \\
\hline$A^{\mathrm{b}}$ & - & 10.4 & 0.50 & 7.25 & 8.63 & 8.36 & 6.83 \\
\hline $\mathbf{B}^{\mathrm{b}}$ & - & 8.21 & 3.35 & 3.88 & 4.15 & 4.02 & 6.79 \\
\hline $\mathbf{C}^{\mathrm{b}}$ & - & 5.96 & 1.43 & 3.70 & 4.06 & 7.80 & 0.63 \\
\hline $\mathbf{D}^{\mathrm{b}}$ & - & 6.83 & 6.18 & 7.15 & 8.25 & 6.70 & 0.74 \\
\hline $\mathbf{E}^{\mathrm{b}}$ & - & 9.67 & 1.02 & 3.22 & 9.07 & 8.23 & 0.55 \\
\hline
\end{tabular}

a From Ref. ${ }^{3 \mathrm{c}}$.

b Data for hCA I, II, IX and XII from Ref. 1, data for hCA VII and XIV this work. c From Ref. ${ }^{4 b}$

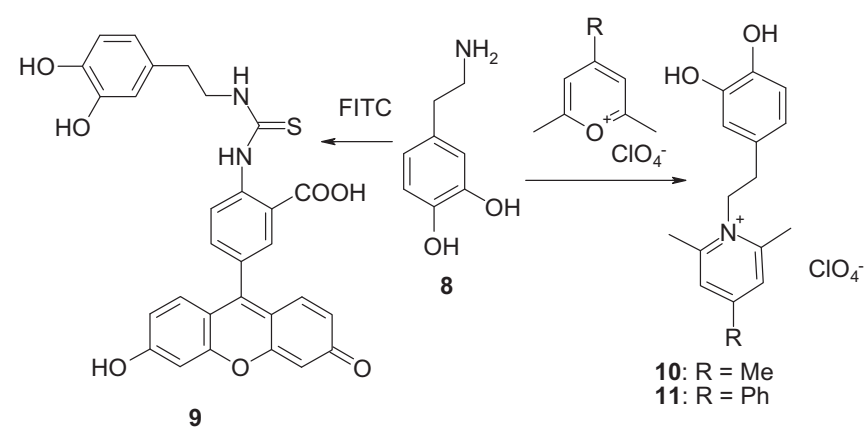

Scheme 1. Preparation of derivatized dopamine derivatives 9-11. 

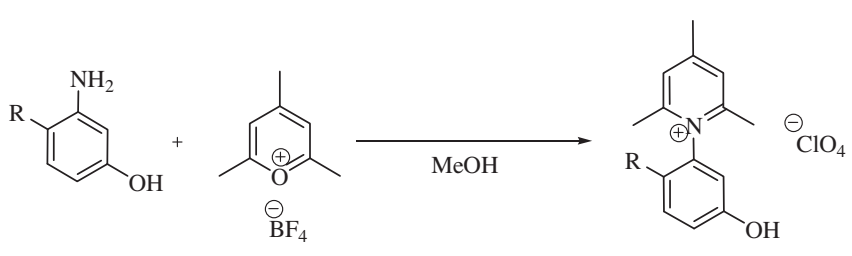

12: $\mathrm{R}=\mathrm{H}$

13: $\mathrm{R}=\mathrm{Cl}$

14: $\mathrm{R}=\mathrm{H}$

15: $\mathrm{R}=\mathrm{Cl}$

Scheme 2. Preparation of pyridinium phenol derivatives 14 and 15.

Table 2

Inhibition data with compounds $\mathbf{9 - 1 5}$, against CA isozymes I, II, VII, IX, XII, and XIV by a stopped-flow technique monitoring the $\mathrm{CO}_{2}$ hydration reaction ${ }^{37}$

\begin{tabular}{llllllll}
\hline \multirow{2}{*}{ No. } & \multirow{2}{*}{$\mathrm{R}$} & \multicolumn{7}{c}{$K_{\mathrm{I}}(\mu \mathrm{M})$} \\
\cline { 3 - 7 } & & hCA I & hCA II & hCA VII & hCA IX & hCA XII & hCA XIV \\
\hline $\mathbf{9}$ & - & 4.8 & 4.4 & 6.8 & 6.7 & 0.73 & 0.71 \\
$\mathbf{1 0}$ & $\mathrm{Me}$ & 7.4 & 6.8 & 8.7 & 0.83 & 0.76 & 0.81 \\
$\mathbf{1 1}$ & $\mathrm{Ph}$ & 5.1 & 4.7 & 7.2 & 0.71 & 0.40 & 0.74 \\
$\mathbf{1 2}$ & $\mathrm{H}$ & 4.9 & 4.7 & 5.9 & 4.9 & 7.7 & 7.2 \\
$\mathbf{1 3}$ & $\mathrm{Cl}$ & 6.3 & 4.9 & 6.4 & 4.7 & 7.5 & 6.4 \\
$\mathbf{1 4}$ & $\mathrm{H}$ & 0.39 & 0.32 & 0.72 & 0.68 & 0.54 & 0.70 \\
$\mathbf{1 5}$ & $\mathrm{Cl}$ & 0.50 & 0.49 & 0.73 & 0.70 & 0.78 & 0.74 \\
\hline
\end{tabular}

and $\mathbf{1 1}$, or aminophenols $\mathbf{1 2}$ and $\mathbf{1 3}$, leading to the pyridinium salts 14 and 15 (Schemes 1 and 2). Dopamine 8 was also reacted with fluorescein isothioyanate (FITC), ${ }^{33}$ leading to the fluorescent thiourea compound $\mathbf{9}$ (Scheme 1 ). This compound was prepared considering the sulfonamides tagged with fluorescent tails derived from FITC, which were essential in demonstrating the role of CA IX in the tumor acidification processes. ${ }^{34}$ Thus, obtaining a fluorescent non-sulfonamide CAI may be useful in biological studies in which the fluorescence is used as a marker of hypoxia or binding to a CA isoform present in that tissue. ${ }^{35}$ The compounds $\mathbf{1 b - 7 d , ~ 9 - 1 1}$ and 14, 15 investigated here were characterized by standard physicochemical and spectral procedures which confirmed their structures (see Section 5 for details).

\section{CA inhibition studies}

Data of Tables 1 and 2 show the CA inhibition data with compounds 1b-7d, 9-11 and 14, 15 reported here and standard inhibitors of types A-E. Six physiologically relevant mammalian CA isoforms have been included in the study: a group of cytosolic isoforms, CA I, II and VII, involved both in important pathologies (e.g., glaucoma (CA II $)^{14}$ or epilepsy (CA VII ${ }^{14 c}$ ), and also considered as offtargets when for example the cancer-associated or mitochondrial enzymes must be inhibited. ${ }^{14}$ The second group of investigated isoforms includes the three transmembrane ones, CA IX, XII and XIV, two of which (CA IX and XII) are associated with the tumor progression and invasion. ${ }^{14 a, b, f, 36}$ The following structureactivity relationship (SAR) can be observed by inspection of data from Tables 1 and 2:

(i) Esters $\mathbf{1 b}-\mathbf{1 d}$ to $\mathbf{7 b}-\mathbf{7 d}$ were generally much more inhibitory (in several cases even orders of magnitude) compared to the corresponding parent carboxylic acid 1a-7a, against most $\mathrm{CA}$ isoforms investigated here. The only exceptions to this rule were five esters, that is, $\mathbf{5 b}$ and $\mathbf{5 c}$ against hCA II and 6b-6d against hCA I and II (Table 1). The parent carboxylic acid 1a-7a usually showed micromolar inhibitory activity against the CA isoforms investigated here, although in several cases their activity was much lower (e.g., 1a against hCA VII and IX, with $\mathrm{K}_{\mathrm{I}} \mathrm{S}$ of $118-716 \mu \mathrm{M}$; 2a against hCA
VII, IX and XIV, with $K_{\mathrm{I}} \mathrm{S}$ of $68-72 \mu \mathrm{M}$; 3a against hCA VII and XIV, etc-see Table 1). Typically, the esterification led to a net increase of the inhibitory power compared to the free carboxylic acid. For example, esters of 4-hydroxybenzoic acid 1a, a very weak hCA VII inhibitor $\left(K_{I}\right.$ of $\left.716 \mu \mathrm{M}\right)$ showed inhibition constants against the same isoform in the range of $0.78-8.7 \mu \mathrm{M}$. The 2,6-dihydroxybenzoic acid 4a was a micromolar hCA I inhibitor $\left(K_{\mathrm{I}}\right.$ of $\left.5.7 \mu \mathrm{M}\right)$ whereas its esters showed $K_{\mathrm{I}} \mathrm{S}$ in the range of $0.68-0.72 \mu \mathrm{M}$ against this isoform. This situation was the one encountered for most of the investigated carboxylic acids/esters from this work. It should be also noted that all esters were more effective CAIs compared to the lead compounds A-E investigated earlier (Table 1$)^{1}$

(ii) The nature of the $\mathrm{R}$ group present in the investigated esters 2b-7d was one of the most important factors influencing CA inhibitory activity, but SAR was not always straightforward. For example, in the case of 2,4-dihydroxybenzoic acid esters $\mathbf{2 b - 2 d , ~ a g a i n s t ~ a l l ~ i s o f o r m s , ~ i n h i b i t o r y ~ a c t i v i t y ~ i n c r e a s e d ~}$ from the methyl to the ethyl and then the isopropyl derivative, in a quasi linear manner (Table 1). However, this simple situation was seen only rarely, for example for the derivatives $\mathbf{3 b - 3 d}$ against isoforms hCA II and VII; $4 \mathbf{b}-\mathbf{4 d}$ against isoforms hCA II and IX or 7b-7d against isoforms hCA II and XIV (Table 1). In most other cases all esters showed a rather compact and similar inhibitory activity. For example, the esters $\mathbf{5 b}-\mathbf{5 d}$ showed $\mathrm{K}_{\mathrm{I}} \mathrm{S}$ in the range of $0.65-0.83 \mu \mathrm{M}$ against hCA I, of $0.75-0.91 \mu \mathrm{M}$ against hCA VII, etc. This was the most typical situation for the compounds investigated here, that is, slight and disordered variation of the inhibitory activity when passing from the methyl to the ethyl and isopropyl derivatives.

(iii) The number of hydroxyl moieties and their positions for the regiomeric dihydroxybenzoic acids also influenced activity of these esters, as observed from data of Table 1 . Thus, the monohydroxy phenols 1b-1d were the least active CAIs against all isoforms investigated here whereas the longer molecule esters of coumaric acid $\mathbf{7 a}$, together with the diphenols $\mathbf{2 b - 2 d}$ to $6 b-6 d$ were stronger, submicromolar CAIs compared to the corresponding esters of 4-hydroxybenzoic acid. The position of the two hydroxyl moieties from these last derivatives with respect to each other and the ester group also influenced activity but to a less extent, since the biological activity of the diphenols was in the same range for the various isomers investigated here (Table 1).

(iv) The dopamine derivatives 9-11 were also effective, low micromolar or submicromolar CAIs, although dopamine itself is a CA activator. ${ }^{12-14}$ Indeed, the activating properties of this amine is due to the proton shuttling capacity of the amino group when the activator is bound within the cavity, which offers an additional pathway for the release of the proton from the water coordinated to zinc to the environment, with formation of the zinc hydroxide species of the enzyme. ${ }^{12-14}$ Blocking the moiety responsible for this process, for example by acylation of the amine group, was shown earlier to lead to the loss of the CA activating effects. 12-14 This was also the case for compounds 9-11 reported here, which acquired CA inhibitory activity. It may be seen from data of Table 2 that $\mathbf{9}$ showed $K_{\mathrm{I}} \mathrm{S}$ in the range of 0.71-6.8 $\mu \mathrm{M}$ against the investigated six CA isoforms; 10 in the range of $0.81-8.7 \mu \mathrm{M}$, and 11 in the range of 0.40 $7.2 \mu \mathrm{M}$, respectively. Thus, compounds $\mathbf{9 - 1 1}$ behave as a typical phenol CAI. The cytosolic isoforms hCA I, II and VII were slightly less sensitive to these compounds compared to the transmembrane isoforms hCA IX, XII and XIV which were generally inhibited almost one order of magnitude more 
efficiently by most of the dopamine derivatives 9-11. Among the pyridinium salts $\mathbf{1 0}$ and $\mathbf{1 1}$, the phenyl-dimethyl-pyridinium derivative $\mathbf{1 1}$ was slightly more effective as a CAI compared to the 2,4,6-trimethylpyridinium derivative $\mathbf{1 0}$.

(v) The aminophenols $\mathbf{1 2}$ and $\mathbf{1 3}$ were low micromolar CAIs against all six CA isoforms investigated here but their derivatization by means of 2,4,6-trimethylpyridinium moieties, as in compounds $\mathbf{1 4}$ and $\mathbf{1 5}$, led to an intensification of these properties, the new compounds being more than one order of magnitude better CAIs compared to the parent aminophenols. Indeed, 14 showed $\mathrm{K}_{\mathrm{I}} \mathrm{S}$ in the range of $0.32-0.72 \mu \mathrm{M}$, whereas 15 in the range of $0.49-0.78 \mu \mathrm{M}$. The presence of the chlorine moiety in $\mathbf{1 5}$ was thus slightly detrimental to the CA inhibitory properties of the compound with respect to the corresponding derivative without the halogen, $\mathbf{1 4 .}$

It should be mentioned that recently Martin and Cohen $^{37}$ reported the X-ray crystal structure of the adducts of three carboxylic acids investigated earlier by us, ${ }^{1} \mathbf{1 a}, \mathbf{3 a}$ and $\mathbf{4 a}$, bound to hCA II (these compounds were used as leads in the present study). In this interesting crystallographic work, our hypothesis was confirmed, since these carboxylates were observed anchored to the zinc bound hydroxide ion/water molecule ${ }^{37}$ (without the necessity to term this already known binding mode by a new, not very happy term, i.e., 'nucleophile recognition'). ${ }^{37}$ Thus, similar to spermine, phenol and some carboxylic acid esters investigated earlier by $\mathrm{X}$-ray crystallography and solution studies, ${ }^{8-10}$ these compounds are not zinc binders, but possess a diverse inhibition mechanism. The interesting study by Martin and Cohen ${ }^{37}$ seems to be flawed by the unusually high inhibition constants reported for these compounds (in the millimolar range) which would in fact not allow the formation of the adducts observed crystallographically. Although an esterase method was used, ${ }^{37}$ which normally gives higher inhibition constants compared to the $\mathrm{CO}_{2}$ hydrase one used by us, we consider that the reported data in the Martin and Cohen's paper ${ }^{37}$ are inconsistent with their own crystallographic study.

\section{Conclusions}

By using hydroxy-/dihydroxybenzoic acids as leads, we report here a series of methyl, ethyl and isopropyl esters of 4hydroxybenzoic, 2,4-, 2,5-, 2,6-, 3,4-, and 3,5-dihydroxybenzoic acids and of coumaric acid. They were investigated for the inhibition of six mammalian CA isoforms, that is, the cytosolic CA I, II and VII, and the transmembrane CA IX, XII and XIV, many of which are established drug targets. Other compounds incorporating phenol/diphenol moieties were obtained from dopamine by reaction with fluorescein isothiocyanate or with 2,4,6-trisubstituted pyrylium salts. Some aminophenols were also derivatized in a similar manner, by using pyrylium salts. Many of these compounds showed increased inhibitory action compared to the lead compounds from which they were obtained, with efficacy in the submicromolar range against most investigated CA isoforms. As phenols are a class of less investigated CA inhibitors (CAIs) compared to the sulfonamides, and their mechanism of inhibition is less well understood, compounds of the type designed here may be helpful in gaining more insights into these phenomena.

\section{Experimental protocols}

\subsection{General}

Anhydrous solvents and all reagents were purchased from Sigma-Aldrich, Alfa Aesar and TCI. All reactions involving air- or moisture-sensitive compounds were performed under a nitrogen atmosphere using dried glassware and syringe techniques to transfer solutions. Infrared (IR) spectra were recorded as $\mathrm{KBr}$ plates and are expressed in $v\left(\mathrm{~cm}^{-1}\right)$. Nuclear magnetic resonance $\left({ }^{1} \mathrm{H}\right.$ NMR, ${ }^{13} \mathrm{C}$ NMR, DEPT, HSQC, HMBC) spectra were recorded using a Bruker Advance III $400 \mathrm{MHz}$ spectrometer in $\mathrm{MeOH}-d_{4}$ or in DMSO$d_{6}$. The chemical shifts are reported in parts per million (ppm) and the coupling constants $(J)$ are expressed in Hertz ( $\mathrm{Hz})$. Splitting patterns are designated as follows: s, singlet; d, doublet; sept, septet; t, triplet; q, quadruplet; m, multiplet; br s, broad singlet; dd, double of doubles, appt, aparent triplet, appq, aparent quartet. The assignment of exchangeable protons $(\mathrm{OH}$ and $\mathrm{NH})$ was confirmed by the addition of $\mathrm{D}_{2} \mathrm{O}$. Analytical thin-layer chromatography (TLC) was carried out on Merck silica gel F-254 plates. Flash chromatography purifications were performed on Merck Silica gel 60 (230-400 mesh ASTM) as the stationary phase and ethyl acetate/n-hexane or $\mathrm{MeOH} / \mathrm{DCM}$ were used as eluents. Melting points (mp) were carried out in open capillary tubes and are uncorrected.

(2E)-3-(4-hydroxyphenyl)-2-propenoic acid, 3-aminophenol, dopamine, FITC, pyrylium salts, 3-amino-4-chlorophenol and the hydroxy/dihydroxybenzoic acids were purchased from SigmaAldrich (Milan, Italy) and used as they are (highest purity available).

\subsection{General procedure for preparation of esters $1 b-7 d^{19,20}$}

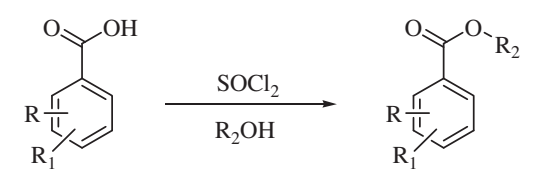

$$
\begin{aligned}
& \mathrm{R}=\mathrm{H}, \mathrm{OH} \\
& \mathrm{R}_{1}=\mathrm{H}, \mathrm{OH} \\
& \mathrm{R}_{2}=\mathrm{Me}, \mathrm{Et},{ }^{i} \mathrm{Pr}
\end{aligned}
$$

Thionyl chloride ( $1.16 \mathrm{~g}, 1.5$ equiv) was added drop-wise to a solution of acid (1.0 g, 1.0 equiv) in the corresponding alcohol $(15 \mathrm{ml})$ at $0{ }^{\circ} \mathrm{C}$. The solution was refluxed under a nitrogen atmosphere until all starting material was consumed (TLC monitoring). Then the solvent was removed under vacuo and the residue was purified by silica gel column chromatography eluting with ethyl acetate $/ n$-hexane to afford the corresponding carboxylic esters.

\subsection{Synthesis of 5-(3-(3,4-dihydroxyphenethyl)thioureido)-2- (3-hydroxy-6-oxo-6H-xanthen-9-yl)benzoic acid 9}

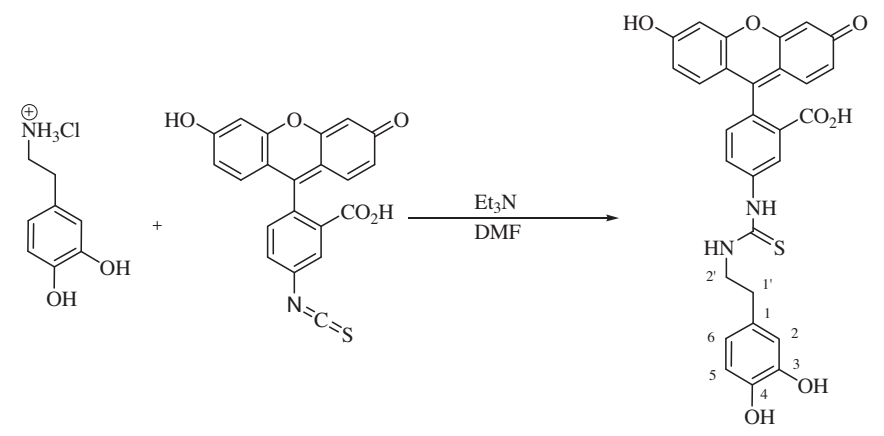

Dopamine hydrochloride ( $0.02 \mathrm{~g}, 1.0$ equiv) and fluoresceine isothiocyanate $(0.04 \mathrm{~g}, 1.0$ equiv) were dissolved in dry DMF 
( $3.0 \mathrm{ml})$ and triethylamine ( $0.01 \mathrm{~g}, 1.0$ equiv) was added drop-wise at $0{ }^{\circ} \mathrm{C}$. The red solution was stirred at $\mathrm{rt}$ under a nitrogen atmosphere for $4 \mathrm{~h}$ (TLC monitoring), quenched with slush and the orange precipitate formed was collected by filtration, washed with $\mathrm{H}_{2} \mathrm{O}(3 \times 10 \mathrm{ml})$ and triturated with diethyl ether to afford the desired product as an orange solid in $55 \%$ yield.

\subsubsection{5-(3-(3,4-Dihydroxyphenethyl)thioureido)-2-(3-hydroxy- 6-oxo-6H-xanthen-9-yl)benzoic acid 9}

Mp $170-175^{\circ} \mathrm{C} ; v_{\max }(\mathrm{KBr}) \mathrm{cm}^{-1}, 3270(\mathrm{O}-\mathrm{H}), 1535$ (aromatic); $\delta_{\mathrm{H}}\left(400 \mathrm{MHz}, \mathrm{DMSO}-d_{6}\right) 2.79\left(2 \mathrm{H}\right.$, appt, $J$ 6.0, 1'- $\left.\mathrm{H}_{2}\right), 3.67(2 \mathrm{H}, \mathrm{q}, J$ 6.0, $\left.1^{\prime}-\mathrm{H}_{2}\right), 6.60-6.80(7 \mathrm{H}, \mathrm{m}, \mathrm{Ar}-\mathrm{H}), 7.20(1 \mathrm{H}, \mathrm{d}, J$ 8.0, Ar-H), 7.80 $\left(1 \mathrm{H}\right.$, br s), $8.05\left(1 \mathrm{H}\right.$, br s, exchange with $\left.\mathrm{D}_{2} \mathrm{O}, \mathrm{CH}_{2} \mathrm{NH}-\right), 8.30(1 \mathrm{H}$, s), $8.80(1 \mathrm{H}, \mathrm{s}), 8.90(1 \mathrm{H}, \mathrm{s}), 10.0(1 \mathrm{H}, \mathrm{br} \mathrm{s}), 10.20(2 \mathrm{H}, \mathrm{s}$, exchange with $\mathrm{D}_{2} \mathrm{O}, \mathrm{CO}_{2} \mathrm{H}$ and $\left.\mathrm{Ar}-\mathrm{NH}\right) ; \delta_{\mathrm{c}}\left(100 \mathrm{MHz}\right.$, DMSO- $\left.d_{6}\right) 181.2(\mathrm{C}=\mathrm{S})$, $172.0(\mathrm{C}=\mathrm{O}), 170.0$ ( $\mathrm{C}=\mathrm{O}$ acid $), 158.6,157.3,155.0,149.0,148.1$, $145.1,136.0,135.6,135.7,134.2,132.0,129.2,128.8,128.6$, $126.4,124.9,122.0,118.0,116.6,116.2,110.0,109.7,105.6,98.3$, 48.0, 34.2 .

5.4. Synthesis of $1^{\prime}$-(3,4-dihydroxyphenethyl)-2 $2^{\prime \prime}, 4^{\prime \prime}, 6^{\prime \prime}$-trimethyl pyridinium tetrafluoroborate 10 and $1^{\prime}$-(3,4-dihydroxypheneth yl)-2", $6^{\prime \prime}$-dimethyl-4" -phenylpyridinium tetrafluoroborate $11^{30}$
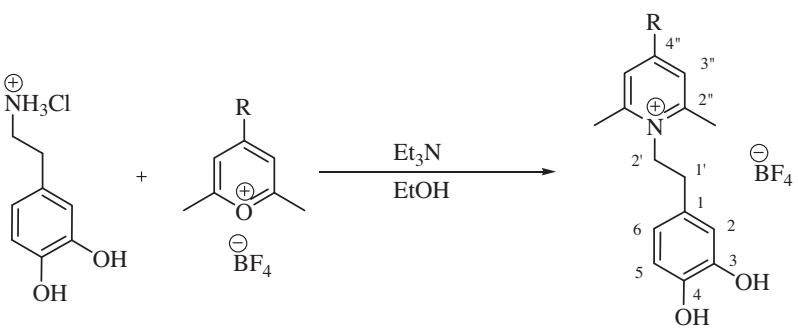

$\mathrm{R}=\mathrm{Me} \mathbf{1 0}$ $\mathrm{R}=\mathrm{Ph} 11$

Dopamine hydrochloride ( $0.5 \mathrm{~g}, 1.0$ equiv) and pyrylium tetrafluoroborate salt (1.2 equiv) were suspended in dry ethanol $(10 \mathrm{ml})$ and the mixture was refluxed for $2 \mathrm{~h}$. Then acetic acid was added $(0.48 \mathrm{~g}, 3.0$ equiv), followed after $1 \mathrm{~h}$ by addition of $30 \%$ aqueous $\mathrm{NH}_{4} \mathrm{OH}(2.0 \mathrm{ml})$. The mixture was cooled down to rt and added to diethyl ether $(30 \mathrm{ml})$. For $\mathbf{1 0}$ a solid was readily obtained and it was collected by filtration, crystallized from $\mathrm{H}_{2} \mathrm{O}$ to afford the desired product as a pale yellow solid in $40 \%$ yield. For 11 a sticky gum was formed which was triturated with diethyl ether and petroleum ether until a semisolid residue was obtained and then recrystallized from $\mathrm{H}_{2} \mathrm{O}$ to afford the desired product as a white solid in $32 \%$ yield.

\subsection{1. $1^{\prime}$-(3,4-Dihydroxyphenethyl)-2" ${ }^{\prime \prime} 4^{\prime \prime}, 6^{\prime \prime}$-trimethylpyridinium} tetrafluoroborate 10

$\mathrm{Mp} 215-220^{\circ} \mathrm{C} ; v_{\max }(\mathrm{KBr}) \mathrm{cm}^{-1}, 3200(\mathrm{O}-\mathrm{H}), 1520$ (aromatic); $\delta_{\mathrm{H}}\left(400 \mathrm{MHz}, \mathrm{DMSO}-d_{6}\right) 2.52\left(3 \mathrm{H}, \mathrm{s}, 4^{\prime \prime}-\mathrm{CH}_{3}\right), 2.76\left(6 \mathrm{H}, \mathrm{s}, 2 \times 2^{\prime \prime}-\right.$ $\left.\mathrm{CH}_{3}\right), 3.00\left(2 \mathrm{H}\right.$, appq, J 8.0, 1'- $\left.\mathrm{H}_{2}\right), 4.59\left(2 \mathrm{H}\right.$, appq, $J$ 8.0, 2'- $\left.\mathrm{H}_{2}\right) 6.48$ (major rotamer, $1 \mathrm{H}$, dd, $J$ 8.0, 1.6, 5-H), 6.63 (major rotamer, $1 \mathrm{H}, \mathrm{d}$, $J$ 1.6, 2-H), 6.71 (major rotamer, $1 \mathrm{H}, \mathrm{d}, J 8.0,6-\mathrm{H}), 7.77(2 \mathrm{H}, \mathrm{s}$, $\left.2 \times 3^{\prime \prime}-\mathrm{H}\right), 8.89\left(2 \mathrm{H}\right.$, br s, exchange with $\left.\mathrm{D}_{2} \mathrm{O}, 2 \times \mathrm{OH}\right) ; \delta_{\mathrm{c}}(100$ $\mathrm{MHz}$, DMSO- $\left.d_{6}\right) 159.2,155.8,152.0,146.0,129.8,129.1,127.3$, 121.6, 117.5, $55.0\left(\mathrm{C}-2^{\prime}\right), 38.8\left(\mathrm{C}-1^{\prime}\right), 22.0\left(2^{\prime \prime}-\mathrm{CH}_{3}\right), 20.8\left(4^{\prime \prime}-\mathrm{CH}_{3}\right)$
5.4.2. 1'-(3,4-Dihydroxyphenethyl)-2",6" ' $^{\prime \prime}$ dimethyl-4" phenylpyridinium tetrafluoroborate 11

Mp 200-203 ${ }^{\circ} \mathrm{C} ; v_{\max }(\mathrm{KBr}) \mathrm{cm}^{-1}, 3220(\mathrm{O}-\mathrm{H}), 1560$ (aromatic); $\delta_{\mathrm{H}}\left(400 \mathrm{MHz}, \mathrm{DMSO}-d_{6}\right) 2.90\left(6 \mathrm{H}, \mathrm{s}, 2 \times 2^{\prime \prime}-\mathrm{CH}_{3}\right), 3.05$ (2H, appt, $J$ 5.6, $\left.1^{\prime}-\mathrm{H}_{2}\right), 4.64\left(2 \mathrm{H}\right.$, appt, J 5.6, 2'- $\left.\mathrm{H}_{2}\right) 6.55(1 \mathrm{H}, \mathrm{dd}, J$ 8.0, 1.6, 5$\mathrm{H}), 6.67(1 \mathrm{H}, \mathrm{d}, J 1.6,2-\mathrm{H}), 6.71(1 \mathrm{H}, \mathrm{d}, J 8.0,6-\mathrm{H}), 7.69(3 \mathrm{H}, \mathrm{m}$, Ar-H), 8.09 (2H, m, Ar-H), 8.38 (2H, s, $\left.2 \times 3^{\prime \prime}-\mathrm{H}\right), 9.01$ (2H, br s, exchange with $\left.\mathrm{D}_{2} \mathrm{O}, 2 \times \mathrm{OH}\right) ; \delta_{\mathrm{c}}\left(100 \mathrm{MHz}\right.$, DMSO- $\left.d_{6}\right) 156.5,154.2$, $146.4,145.4,134.4,132.9,130.6,128.8,128.2,125.1,120.6$, $117.3,116.7,54.3\left(\mathrm{C}-2^{\prime}\right), 33.7\left(\mathrm{C}-1^{\prime}\right), 21.6\left(\mathrm{CH}_{3}\right)$.

\subsection{Synthesis of 1-(3-hydroxyphenyl)-2' $\mathbf{4}^{\prime}, 6^{\prime}$-trimethylpyridi} nium $14^{31}$ and 1-(2-chloro-5-hydroxyphenyl)-2', $4^{\prime}, 6^{\prime}$-trim ethylpyridinium 15
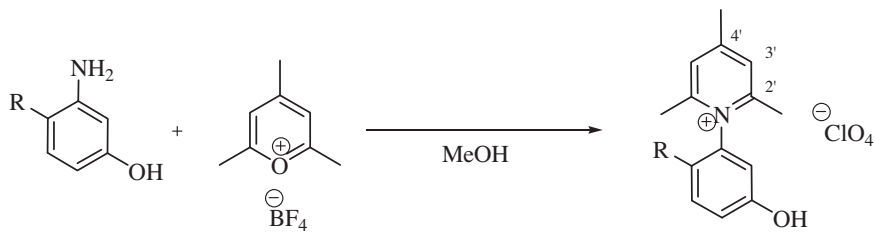

$\mathrm{R}=\mathrm{H} \quad \mathbf{1 4}$

$$
\mathrm{R}=\mathrm{Cl} 15
$$

The appropriate aminophenol ( $0.5 \mathrm{~g}, 1.0$ equiv) and 2,4,6trimethylpyrylium tetrafluoroborate (1.2 equiv) were dissolved in dry methanol $(10 \mathrm{ml})$ and the solution was refluxed for $5 \mathrm{~h}$. Then solvent was partially removed, the mixture was cooled to $\mathrm{rt}$ and treated with a $1.0 \mathrm{M}$ aqueous solution of $\mathrm{HClO}_{4}$ (3.0 equiv). The precipitate formed was collected by filtration, and crystallized from $\mathrm{H}_{2} \mathrm{O}$ to afford the corresponding pyridinium perchlorate salts $\mathbf{1 4}$ and $\mathbf{1 5}$ as white solids in 38\% and 32\% yield respectively.

\subsubsection{1-(3-Hydroxyphenyl)-2,4,6-trimethylpyridinium 14}

Mp $158-161^{\circ} \mathrm{C}$ ( Lit. $\left.^{31} 156^{\circ} \mathrm{C}\right) ; v_{\max }(\mathrm{KBr}) \mathrm{cm}^{-1}, 3300(\mathrm{O}-\mathrm{H})$ 1580 (aromatic); $\delta_{\mathrm{H}}\left(400 \mathrm{MHz}, \mathrm{DMSO}-d_{6}\right) 2.37\left(6 \mathrm{H}, \mathrm{s}, 2 \times 2^{\prime}-\mathrm{CH}_{3}\right)$, $2.63\left(3 \mathrm{H}, \mathrm{s}, 4^{\prime}-\mathrm{CH}_{3}\right), 6.99(2 \mathrm{H}, \mathrm{m}, 2-\mathrm{H}$ and $4-\mathrm{H}), 7.12(1 \mathrm{H}, \mathrm{dd}, J$ 8.2, 1.6, 6-H), $7.76(1 \mathrm{H}$, appt, $J 8.2,5-\mathrm{H}), 7.94\left(2 \mathrm{H}, \mathrm{s}, 2 \times 3^{\prime}-\mathrm{H}\right)$, $10.34\left(1 \mathrm{H}\right.$, br s, exchange with $\left.\mathrm{D}_{2} \mathrm{O}, \mathrm{OH}\right) ; \delta_{\mathrm{c}}\left(100 \mathrm{MHz}\right.$, DMSO- $\left.d_{6}\right)$ $160.0,155.2,137.0,133.1,128.6,120.0,118.2,115.7,112.2,22.4$ $\left(4^{\prime}-\mathrm{CH}_{3}\right), 21.5\left(2^{\prime}-\mathrm{CH} 3\right)$.

\subsubsection{1-(2-Chloro-5-hydroxyphenyl)-2', $4^{\prime}, 6^{\prime}$-trimethylpyridi nium 15}

Mp $145^{\circ} \mathrm{C} ; v_{\max }(\mathrm{KBr}) \mathrm{cm}^{-1}, 3360(\mathrm{O}-\mathrm{H}), 1560$ (aromatic); $\delta_{\mathrm{H}}$ $\left(400 \mathrm{MHz}, \mathrm{DMSO}-d_{6}\right) 2.38\left(6 \mathrm{H}, \mathrm{s}, 2 \times 2^{\prime}-\mathrm{CH}_{3}\right), 2.67\left(3 \mathrm{H}, \mathrm{s}, 4^{\prime}-\mathrm{CH}_{3}\right)$ $7.19(1 \mathrm{H}, \mathrm{dd}, J 8.0,1.6,4-\mathrm{H}), 7.27(1 \mathrm{H}, \mathrm{d}, J 1.6,6-\mathrm{H}), 7.23(1 \mathrm{H}, \mathrm{d}, J$ 8.0, 3-H), $8.04\left(2 \mathrm{H}, \mathrm{s}, 2 \times 3^{\prime}-\mathrm{H}\right), 10.74\left(1 \mathrm{H}, \mathrm{s}\right.$, exchange with $\mathrm{D}_{2} \mathrm{O}$ $\mathrm{OH}) ; \delta_{\mathrm{c}}\left(100 \mathrm{MHz}, \mathrm{DMSO}-d_{6}\right), 161.4,159.3,155.4,136.6,132.9$, 128.5, 121.1, 117.9, 115.5, $22.4\left(4^{\prime}-\mathrm{CH}_{3}\right), 21.5\left(2^{\prime}-\mathrm{CH}_{3}\right)$.

\subsection{CA inhibition}

An Applied Photophysics stopped-flow instrument has been used for assaying the CA catalyzed $\mathrm{CO}_{2}$ hydration activity. Phenol red (at a concentration of $0.2 \mathrm{mM}$ ) has been used as indicator, working at the absorbance maximum of $557 \mathrm{~nm}$, with $20 \mathrm{mM}$ Hepes (pH 7.4) as buffer, and $20 \mathrm{mM} \mathrm{Na}_{2} \mathrm{SO}_{4}$ (for maintaining constant the ionic strength), following the initial rates of the CA-catalyzed $\mathrm{CO}_{2}$ hydration reaction for a period of $10-100 \mathrm{~s}^{38}$ The $\mathrm{CO}_{2}$ 
concentrations ranged from 1.7 to $17 \mathrm{mM}$ for the determination of the kinetic parameters and inhibition constants. For each inhibitor at least six traces of the initial $5-10 \%$ of the reaction have been used for determining the initial velocity. The uncatalyzed rates were determined in the same manner and subtracted from the total observed rates. Stock solutions of inhibitor $(10 \mathrm{mM})$ were prepared in distilled-deionized water and dilutions up to $0.001 \mathrm{nM}$ were done thereafter with the assay buffer. Inhibitor and enzyme solutions were preincubated together for $15 \mathrm{~min}$ at room temperature prior to assay, in order to allow for the formation of the E-I complex (the proteins were incubated also for longer periods, of 1-24 h, but no differences of activity have been detected). The inhibition constants were obtained by non-linear least-squares methods using PRISM 3, as reported earlier, ${ }^{1,6}$ and represent the mean from at least three different determinations. All CA isoforms were recombinant ones obtained in house as reported earlier. ${ }^{6-9}$

\section{Acknowledgments}

This research was financed by a 7th FP EU project (Metoxia). Thanks are addressed to Dr. Alessio Innocenti who was involved in the first phases of this research.

\section{Supplementary data}

Supplementary data associated with this article can be found, in the online version, at http://dx.doi.org/10.1016/j.bmc.2012.05.019.

\section{References and notes}

1. Durdagi, S.; Şentürk, M.; Ekinci, D.; Türker Balaydın, H.; Göksu, S.; Küfrevioğlu, I. Ö.; Innocenti, A.; Scozzafava, A.; Supuran, C. T. Bioorg. Med. Chem. 2011, 19, 1381.

2. Nair, S. K.; Ludwig, P. A.; Christianson, D. W. J. Am. Chem. Soc. 1994, 116, 3659.

3. (a) Innocenti, A.; Vullo, D.; Scozzafava, A.; Supuran, C. T. Bioorg. Med. Chem. Lett. 2008, 18, 1583; (b) Innocenti, A.; Hilvo, M.; Scozzafava, A.; Parkkila, S. Supuran, C. T. Bioorg. Med. Chem. Lett. 2008, 18, 3593; (c) Innocenti, A.; Vullo, D.; Scozzafava, A.; Supuran, C. T. Bioorg. Med. Chem. 2008, 16, 7424; (d) Bayram, E.; Senturk, M.; Kufrevioglu, O. I.; Supuran, C. T. Bioorg. Med. Chem. 2008, 16 9101; Ekinci, D.; Karagoz, L.; Ekinci, D.; Senturk, M.; Supuran, C.T. J. Enzyme Inhib. Med. Chem. in press (doi: http://dx.doi.org/10.3109/ 14756366.2011.643303).

4. (a) Sentürk, M.; Gülçin, I.; Daştan, A.; Küfrevioğlu, Ö. I.; Supuran, C. T. Bioorg. Med. Chem. 2009, 17, 3207; (b) Innocenti, A.; Öztürk Sarıkaya, S. B.; Gülçin, I.; Supuran, C. T. Bioorg. Med. Chem. 2010, 18, 2159; (c) Innocenti, A.; Gülçin, I.; Scozzafava, A.; Supuran, C. T. Bioorg. Med. Chem. Lett. 2010, 20, 5050; (d) Davis, R. A.; Innocenti, A.; Poulsen, S. A.; Supuran, C. T. Bioorg. Med. Chem. 2010, 18, 14

5. (a) Almajan, G. L.; Innocenti, A.; Puccetti, L.; Manole, G.; Barbuceanu, S.; Saramet, I.; Scozzafava, A.; Supuran, C. T. Bioorg. Med. Chem. Lett. 2005, 15, 2347; (b) Schulze Wischeler, J.; Innocenti, A.; Vullo, D.; Agrawal, A.; Cohen, S. M.; Heine, A.; Supuran, C. T.; Klebe, G. ChemMedChem. 2010, 5, 1609.

6. (a) Maresca, A.; Temperini, C.; Vu, H.; Pham, N. B.; Poulsen, S. A.; Scozzafava, A.; Quinn, R. J.; Supuran, C. T. J. Am. Chem. Soc. 2009, 131, 3057; (b) Maresca, A.; Temperini, C.; Pochet, L.; Masereel, B.; Scozzafava, A.; Supuran, C. T. J. Med. Chem. 2010, 53, 335.

7. (a) Maresca, A.; Supuran, C. T. Bioorg. Med. Chem. Lett. 2010, 20, 4511; (b) Maresca, A.; Scozzafava, A.; Supuran, C. T. Bioorg. Med. Chem. Lett. 2010, 20 , 7255; (c) Touisni, N.; Maresca, A.; McDonald, P. C.; Lou, Y.; Scozzafava, A.; Dedhar, S.; Winum, J. Y.; Supuran, C. T. J. Med. Chem. 2011, 54, 8271; (d) Bonneau, A.; Maresca, A.; Winum, J.Y.; Supuran, C.T. J. Enzyme Inhib. Med. Chem., in press.

8. (a) Carta, F.; Maresca, A.; Scozzafava, A.; Supuran, C. T. Bioorg. Med. Chem. Lett. 2012, 22, 267; (b) Carta, F.; Vullo, D.; Maresca, A.; Scozzafava, A.; Supuran, C. T. Bioorg. Med. Chem. Lett. 2012, 22, 2182; (c) Carta, F.; Maresca, A.; Scozzafava, A.; Supuran, C. T. Bioorg. Med. Chem. 2012, 20, 2266.

9. Temperini, C.; Innocenti, A.; Scozzafava, A.; Parkkila, S.; Supuran, C. T. J. Med. Chem. 2010, 53, 850.
10. Carta, F.; Temperini, C.; Innocenti, A.; Scozzafava, A.; Kaila, K.; Supuran, C. T. J. Med. Chem. 2010, 53, 5511.

11. Innocenti, A.; Durdagi, S.; Doostdar, N.; Strom, T. A.; Barron, A. R.; Supuran, C. T. Bioorg. Med. Chem. 2010, 28, 2822.

12. (a) Dave, K.; Ilies, M. A.; Scozzafava, A.; Temperini, C.; Vullo, D.; Supuran, C. T. Bioorg. Med. Chem. Lett. 2011, 21, 2764; (b) Dave, K.; Scozzafava, A.; Vullo, D.; Supuran, C. T.; Ilies, M. A. Org. Biomol. Chem. 2011, 9, 2790.

13. (a) Alterio, V.; Di Fiore, A.; D’Ambrosio, K.; Supuran, C. T.; De Simone, G. X-Ray Crystallography of CA Inhibitors and its Importance in Drug Design. In Drug Design of Zinc-Enzyme Inhibitors: Functional, Structural, and Disease Applications; Supuran, C. T., Winum, J. Y., Eds.; Wiley: Hoboken, 2009; pp 73-138; (b) Alterio, V.; Vitale, R. M.; Monti, S. M.; Pedone, C.; Scozzafava, A.; Cecchi, A.; De Simone, G.; Supuran, C. T. J. Am. Chem. Soc. 2006, 128, 8329.

14. (a) Supuran, C. T. Nat. Rev. Drug Disc. 2008, 7, 168; (b) Neri, D.; Supuran, C. T. Nat. Rev. Drug Disc. 2011, 10, 767; (c) Supuran, C. T. Bioorg. Med. Chem. Lett. 2010, 20, 3467; (d) Supuran, C. T.; Scozzafava, A.; Casini, A. Med. Res. Rev. 2003, 23, 146; (e) Supuran, C. T.; Vullo, D.; Manole, G.; Casini, A.; Scozzafava, A. Curr. Med. Chem. Cardiovasc. Hematol. Agents 2004, 2, 49; (f) Supuran, C. T. Curr. Pharm. Des. 2010, 16, 3233.

15. (a) Avvaru, B. S.; Wagner, J. M.; Maresca, A.; Scozzafava, A.; Robbins, A. H.; Supuran, C. T.; McKenna, R. Bioorg. Med. Chem. Lett. 2010, 20, 4376; (b) Wagner, J. M.; Avvaru, B. S.; Robbins, A. H.; Scozzafava, A.; Supuran, C. T.; McKenna, R. Bioorg. Med. Chem. 2010, 18, 4873; (c) Pacchiano, F.; Aggarwal, M.; Avvaru, B. S.; Robbins, A. H.; Scozzafava, A.; McKenna, R.; Supuran, C. T. Chem. Commun. 2010, 46, 8371 .

16. (a) De Simone, G.; Supuran, C.T. J. Inorg. Biochem. in press.; (b) Parkkila, S.; Vullo, D.; Maresca, A.; Carta, F.; Scozzafava, A.; Supuran, C. T. Chem. Commun. 2012, 48, 3551 .

17. (a) Carta, F.; Aggarwal, M.; Maresca, A.; Scozzafava, A.; McKenna, R.; Supuran, C. T. Chem. Commun. 1868, 2012, 48; (b) Maresca, A.; Carta, F.; Vullo, D.; Supuran, C.T. J. Enzyme Inhib. Med. Chem. in press.; (c) Monti, S. M.; Maresca, A.; Carta, F.; De Simone, G.; Mühlschlegel, F. A.; Scozzafava, A.; Supuran, C. T. Bioorg. Med. Chem. Lett. 2012, 22, 859; (d) Carta, F.; Aggarwal, M.; Maresca, A.; Scozzafava, A.; McKenna, R.; Masini, E.; Supuran, C. T. J. Med. Chem. 2012, 55, 1721.

18. Temperini, C.; Vullo, D.; Scozzafava, A.; Supuran, C. T. J. Med. Chem. 2006, 49, 3019.

19. Gianolio, E.; Giovenzana, G. B.; Ciampa, A.; Lanzardo, S.; Imperio, D.; Aime, S. ChemMedChem 2008, 3, 60.

20. Singh, P. P.; Chauhan, S. M. S. Synthetic Commun. 2008, 38, 928.

21. Neelakantan, S.; Padmasani, R.; Seshadri, T. R. Tetrahedron 1965, 21, 35313536.

22. Rose, N. R.; Ng, S. S.; Mecinovic, J.; Lienard, B. M. R.; Bello, S. H.; Sun, Z.; McDonough, M. A.; Oppermann, U.; Schofield, C. J. J. Med. Chem. 2008, 51, 7053-7056.

23. Hansen, P. E.; Christoffersen, M.; Bolvig, S. Magn. Reson. Chem. 1993, 31, 893.

24. Ploypradith, P.; Cheryklin, P.; Niyomtham, N.; Bertoni, D. R.; Ruchirawat, S. Org. Lett. 2007, 9, 2637-2640.

25. Mahendran, A.; Vuong, A.; Aebisher, D.; Gong, Y.; Bittman, R.; Arthur, G.; Kawamura, A.; Greer, A. J. Org. Chem. 2010, 75, 5549.

26. Kumar, N. S. S.; Varghese, S.; Narayan, G.; Das, S. Angew. Chem., Int. Ed. 2006, 45, 631.

27. (a) Lestini, E.; Nikitin, K.; Mueller-Bunz, H.; Fitzmaurice, D. Chem. Eur. J. 2008, 14, 1095; (b) Hou, B.-Y.; Wang, D.-X.; Yang, H.-B.; Zheng, Q.-Y.; Wang, M.-X. J. Org. Chem. 2007, 14, 5218.

28. El-Ghazooly, M. G.; El-Lakany, A. M.; Abou-Shoer, M. I.; Aly, A. H. Nat. Prod. Sci. 2003, 4, 213.

29. (a) Chae, J. Arch. Pharm. Res. 2008, 31, 305; (b) Magano, J.; Chen, M. H.; Clark, J. D.; Nussbaumer, T. J. Org. Chem. 2006, 71, 7103.

30. (a) Ilies, M. A.; Seitz, W. A.; Ghiviriga, I.; Johnson, B. H.; Miller, A.; Thompson, E. B.; Balaban, A. T. J. Med. Chem. 2004, 15, 3744; (b) Supuran, C. T.; Baciu, I.; Balaban, A. T. Rev. Roum. Chim. 1993, 38, 725.

31. Dinculescu, A.; Fahmy, M.; Chiraleu, F.; Balaban, A. T. Rev. Roum. Chim. 1983, 28, 699.

32. Scozzafava, A.; Briganti, F.; Ilies, M. A.; Supuran, C. T. J. Med. Chem. 2000, 43, 292

33. Menchise, V.; De Simone, G.; Alterio, V.; Di Fiore, A.; Pedone, C.; Scozzafava, A.; Supuran, C. T. J. Med. Chem. 2005, 48, 5721.

34. Cecchi, A.; Hulikova, A.; Pastorek, J.; Pastoreková, S.; Scozzafava, A.; Winum, J. Y.; Montero, J. L.; Supuran, C. T. J. Med. Chem. 2005, 48, 4834.

35. Švastová, E.; Hulíková, A.; Rafajová, M.; Zatovicová, M.; Gibadulinová, A.; Casini, A.; Cecchi, A.; Scozzafava, A.; Supuran, C. T.; Pastorek, J.; Pastoreková, S. FEBS Lett. 2004, 577, 439.

36. Dubois, L.; Lieuwes, N. G.; Maresca, A.; Thiry, A.; Supuran, C. T.; Scozzafava, A.; Wouters, B. G.; Lambin, P. Radiother. Oncol. 2009, 92, 423.

37. Martin, D. P.; Cohen, S. M. Chem. Commun. (Camb). 2012, 48, 5259.

38. Khalifah, R. G. J. Biol. Chem. 1971, 246, 2561. 